\title{
Acknowledgments
}

As I am faced with the daunting task of thanking the individuals and institutions that have made this book possible, I am reminded of just how incredibly lucky I have been during the time that I conceived and carried out this project. Friends, family, and colleagues have supported me in ways both little and big along the way.

At least in my humble opinion, a young scholar could not have asked for better mentors than John Beatty and Sheila Jasanoff. John is one of the nicest people I've ever met and the best teacher I've ever had. Throughout the past several years, he has not only asked me to be the best historian I can be, but also the best person I can be. For both, and especially the latter, I cannot thank him enough. Sheila is, quite simply, present on each and every page of this book, even when it is not entirely apparent. Through her research, teaching, innumerable long conversations, as well as the invigorating STS community that she has created at Harvard University's Kennedy School of Government, Sheila provided me with the intellectual resources necessary to write this book.

While in Minneapolis, I was thankful for the companionship of my fellow graduate students who supported me through two years of coursework. Perhaps the most important person at Minnesota, though, was Barbara Eastwold, who not only resolved seemingly endless bureaucratic crises for me but also managed to brighten my day every time I came to see her. I wrote the bulk of this book in Cambridge, Massachusetts, where I benefited a great deal from my interactions with members of the vibrant STS community at the Kennedy School. Kaushik Sunder Rajan, Jenny Reardon, and David Winickoff deserve special thanks for many interesting conversations and debates. Steve Hilgartner gave me my first course in conducting oral history interviews shortly before I began doing my research. More than seventy interviews later, his advice still comes in handy. Mike Lynch and Simon Cole have also provided me with a tremendous amount of support and have contributed in numerous ways to the creation of this work. Thanks must also go to Dick Lewontin, who provided me with office space when 
I first arrived in Cambridge and served as my tutor in molecular biology and population genetics while I wrote this book. He was also the first person to read the completed draft of my dissertation. Those who know Dick won't be surprised to learn that he was more critical of my work than almost anyone else who read it. His comments dramatically improved my thinking, and he can take credit for making me treat science seriously. (Any errors, of course, remain entirely my fault.) Thanks also go to several people who have helped me at various stages of my career and with this book, especially Caroline Acker, Pnina Abir-Am, Jennifer Alexander, Michael Dietrich, Greg Gibson, David Hounshell, Jay Kadane, Sally Kohlstedt, Arthur Norberg, Mark Perlin, Joyce Seltzer, Alan Shapiro, Joel Tarr, Joe Trotter, and Susan Wolf.

It has been a pleasure to work with Rutgers University Press on this project. Thanks go to Audra Wolfe for helping me shape the story that is told within these pages, and Doreen Valentine for her tireless efforts to make my writing crisp and coherent. An author could not ask for better editors. Monica Phillips and Marilyn Campbell did an excellent job of turning my rough manuscript into a polished book.

Research on recent science, not to mention science in the legal system, poses significant challenges to the historian. To begin with, almost all of the participants in the story I tell are still alive today. Indeed, most are currently at the peak of their careers. Therefore, I must begin by thanking the sixty-plus individuals who took time out of their busy schedules to discuss their roles in the development of DNA typing. Special thanks go to George Sensabaugh from the University of California at Berkeley and William Thompson from the University of California at Irvine for devoting many hours over many days to help me understand the multiple interpretations of the history of DNA profiling.

Among the most difficult challenges to overcome are the sheer volume of relevant information and the difficulty in gaining access to the most interesting materials. Therefore, I must acknowledge the following institutions and individuals for their help with this process. The Cornell University Library Division of Rare Books and Manuscripts collection on the O.J. Simpson Trial and DNA Typing Archive proved to be the single most important source of documents during my research. This collection contains the entire set of Frye Hearing Transcripts from NY v. Castro, as well as various other transcripts, interviews, and other crucial materials. These items can be found in the "O.J. Simpson Murder Trial and DNA Typing Archive," \#53/12/3037. I cannot begin to give adequate thanks to the people who had the foresight to put this collection together (especially Sheila Jasanoff, Steve Hilgartner, and Bruce Lewenstein).

Arthur Daemmrich of the Chemical Heritage Foundation provided access to publicity materials (brochures, pamphlets, fee schedules, advertisements, etc.) and protocols of Lifecodes and Cellmark. He obtained these materials while doing graduate research on the business side of forensic DNA analysis in the mid-1990s. Daemmrich recently transferred his collection to the O.J. Simpson 
Murder Trial and DNA Typing Archive at Cornell, which he helped put together. Individuals wishing to access this collection should consult the archivist at Cornell's Rare and Manuscripts Collections.

The Hennepin County District Attorney's Office provided access to case files of State of Minnesota v. Thomas Schwartz, 1989 (SIP No. 89903565/C.A. No. 88-3195) and State of Minnesota v. Larry Lee Jobe, 1990 (SIP No. 88903565/C.A. No. 88-3301; Hennepin County District Court).

Richard C. Lewontin of Harvard University provided access to a multitude of materials relating to the debate over population genetics issues, as well as transcripts and court documents from United States v. Yee, et al., from his private collection.

The National Academy of Sciences Archive, National Research Council Commission on Life Sciences: Board on Biology Archives (NAS Library, Washington, D.C.) provided access to nonclassified materials from the two National Research Council reports on forensic DNA analysis. Thanks to archivist Janice Goldblum for all of her help.

Kellie Nielan from the Florida Attorney General's Office, Daytona Beach, provided access to the "Answer Brief of Appellee" and "Amicus Curae" (by Andre Moennsens) in Tommie Lee Andrews v. State of Florida, 1988 (Case No. 87-2166; Fifth District, Florida Court of Appeal).

William C. Thompson of University of California-Irvine, provided me with access to materials related to the CACLD and the FBI as well as numerous court transcripts and other documents from his private collection.

Jan Witkowski from the Banbury Center at Cold Spring Harbor Laboratory provided access to his files relating to the Banbury Meeting on "DNA Technology and Forensic Science," the New York State Forensic DNA Analysis Panel, as well as a transcript of the Frye Hearing in New York v. Wesley-Bailey. These materials can be accessed through the Cold Spring Harbor Laboratory Archive, Box Containing Jan Witkowksi's Materials Related to DNA Fingerprinting and the Banbury Conference on "DNA Technology and Forensic Science," which is uncataloged at the present time.

The following records of U.S. Congressional Hearings provided a rich source of otherwise difficult-to-obtain documents, correspondence, and other materials: (1) "DNA Identification," Hearing before the Subcommittee on Constitution of the Committee on the Judiciary, United States Senate, First Session on "Genetic Testing as a means of Criminal Investigation," 15 March 1989, Serial \#J-101-4 (Washington, D.C.: U.S. Government Printing Office, 1990); (2) "FBI Oversight and Authorization Request for Fiscal Year 1990 (DNA Identification)” Hearing, House of Representatives, Subcommittee on Civil and Constitutional Rights, Committee on Judiciary, 22 March 1989 (Washington, D.C.: U.S. Government Printing Office, 1990); and (3) "Forensic DNA Analysis," Joint Hearing before the Subcommittee on Civil and Constitutional Rights of the House Committee on the Judiciary and the Subcommittee on the Constitution of the Senate Committee on 
the Judiciary, 13 June 1991, House Serial 30/Senate Serial J-102-47 (Washington, D.C.: U.S. Government Printing Office, 1992).

Thanks also go to Graham Cooke in London and Peter Donnelly in Oxford for access to material relating to the use of DNA evidence in Great Britain.

It is an understatement to say that this book would not exist without the love and support that I have received from family, especially Karen and Richard Heilman, Amy Heilman, Muriel Baum, and my late grandmother, Norma Heilman. Everything that I have achieved, and everything that I will achieve, is born from their generosity, compassion, and kindness. The Dubowitz and Faiman families have welcomed me into their hearts and homes (around the world) in a way that exceeded my wildest expectations. Dubie and Jean shower warmth, affection, encouragement, and love upon me as if I were their own son, and Granny Bubbles (a.k.a. Marion Faiman) has inspired me with her energy, curiosity about my work, and zest for life.

Finally, this book is dedicated to the two most important people in my life. To Tamara for making me whole, allowing me to feel true love, being my best friend, challenging me to think deeply and differently about the world, making each and every moment of my existence special, and so, so, so much more. I love you more than life itself. And to Ezra, you are not only the cutest child ever to walk the face of the earth, but you are also my constant source of inspiration, joy, and wonder-you continue to teach me how profound love can be. 


\section{Genetic Witness}

00000000000000000000000000000000000000000000000000000000000000000000000000000000 
